\title{
Correction to: Exploring Motivation for Listed Companies and Measures Taken Towards Managing Environmental Collision: Evidence from Sri Lanka
}

I. M. Withanawasam, G. Wickremasinghe, and M. Naidoo

\section{Correction to: \\ Chapter 10 in: S. Dhiman, R. Samaratunge (eds.), New Horizons in Management, Leadership and Sustainability, Future of Business and Finance, https://doi.org/10.1007/978-3-030-62171-1_10}

Owing to an oversight, in the affiliation of the author G. Wickremasinghe M. Naidoo, "Victoria University" is missing after "Victoria University Business School". The corrected affiliation should read as below:

G. Wickremasinghe $\cdot$ M. Naidoo

Victoria University Business School, Victoria University

Melbourne, Australia 